\title{
Hvordan er støttekollegaordningen nyttig?
}

«Særlig når ens eget nettverk ikke strekker til, eller kan brukes i den aktuelle situasjonen, kan hjelp fra en støttekollega være avgjørende.»

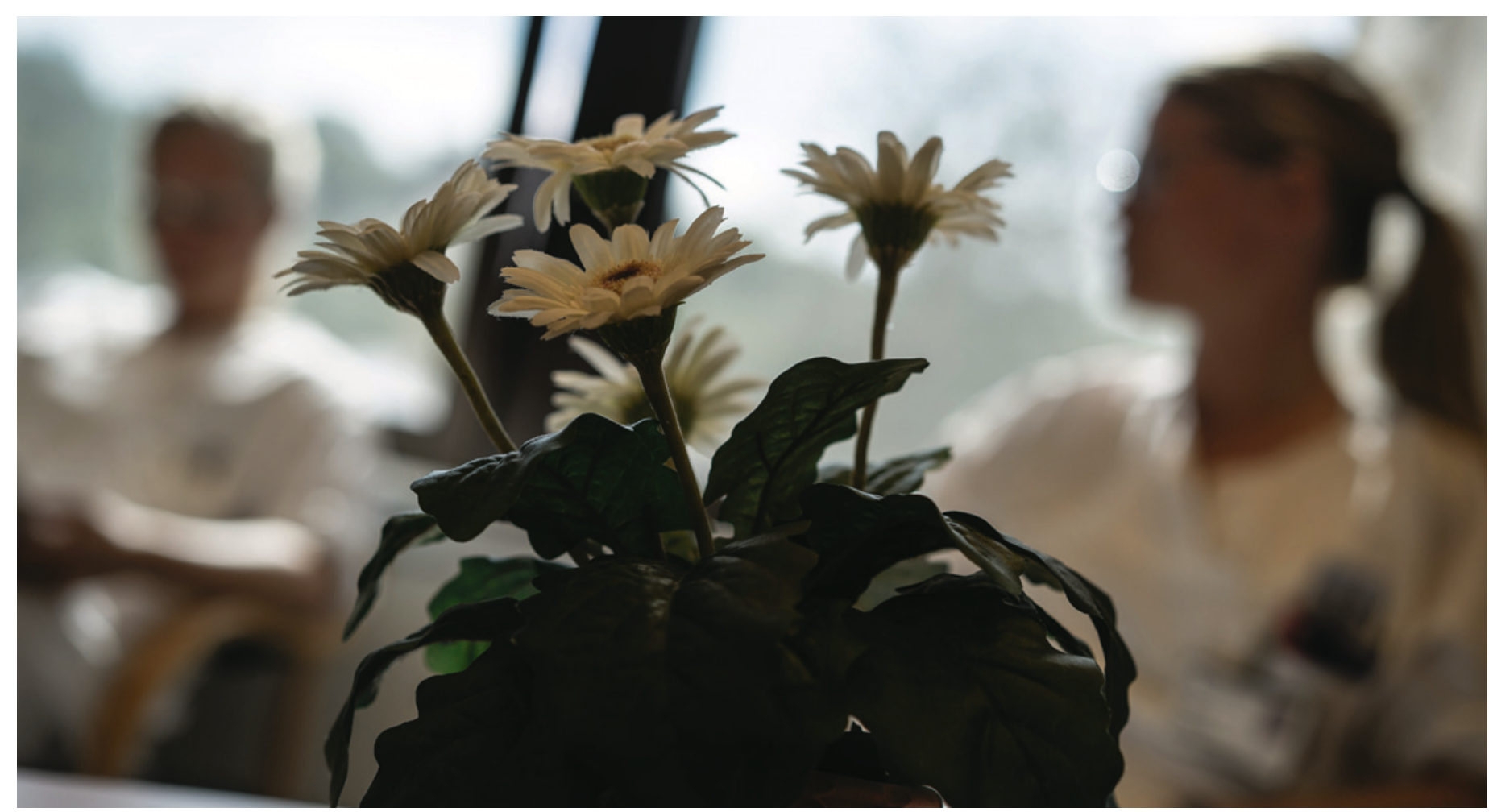

Illustrasjonsfoto: Ole Kristian Losvik

I de etiske reglene for leger oppfordres leger til å hjelpe, råde og veilede kolleger samt tilby hjelp ved sykdom eller rusmiddelmisbruk (kapittel 2 § 2-3). I tråd med dette har Legeforeningen siden begynnelsen av 1990årene organisert et landsdekkende tilbud der erfarne leger (fra flere spesialiteter) i hvert fylke oppnevnes som støttekolleger (1).

Leger som kontakter støttekollegaordningen, får raskt et tilbud om inntil tre samtaler. Det er gratis for den enkelte lege og tilbudet kan benyttes uavhengig av medlemskap i foreningen. Ordningen betales av Sykehjelps- og pensjonsordningen for leger (SOP), begrunnet i denne stiftelsens formålsparagraf om å «yte støtte til kollektive sykdomsforebyggende tiltak for medlemmer». Samtalen er kollegial og regnes ikke som behandling. Den journalføres ikke og er helt konfidensiell.

For å få innblikk i hvordan støttekolleger oppfatter nytten av - og beskriver bruken av - ordningen gjorde vi en fokusgruppestudie med intervjuer av støttekolleger fra alle fylker (2). Sitatet over er hentet fra ett av intervjuene.
Den fleksible, konfidensielle og ikkebyråkratiske organiseringen beskrives som en viktig forutsetning for at leger skal oppsøke ordningen og for at de i noen tilfeller søker hjelp i det hele tatt (3). Støttekollegene erfarer at det er viktig for dem som søker hjelp å bli lyttet til. Samtalen kan være en første høyttenkning der man får hjelp til å sortere, strukturere og diskutere veivalg og håndtering $\mathrm{av}$ ulike $\mathrm{og}$ ofte sammensatte problemstillinger.

Vi vet at leger ofte nøler med å søke behandling. Samtalen(e) med støttekollegaen ser i mange tilfeller ut å senke terskelen for å innhente videre råd eller behandling hvis det er behov for det. Dermed bidrar trolig ordningen til å legitimere at også leger har behov for støtte og hjelp (3). Samtidig er det viktig å ha en pågående diskusjon om hvordan rammene for ordningen ivaretar både risikoen for suboptimal behandling av pasientene og behov for nødvendig behandling for legen (4).

Støttekollegaordningen beskrives i intervjuene som en viktig beredskapsordning. Den må være på plass i situasjoner som kan oppleves som truende eller krevende for leger på ulike måter (3). Kolleger som er i konflikt eller i vanskelige arbeidsforhold, vil ofte trenge en personlig kontakt. Den individuelle støtten som tilbys er viktig, men det understrekes at den av støttekollegene ikke skal bidra til å opprettholde systemsvikt som må håndteres av ledelse, tillitsvalgte eller via andre kanaler på arbeidsplassen $(3,4)$.

\section{Karin Isaksson Rø}

LEFO - Legeforeningens forskningsinstitutt

Litteratur

1. Helse- og omsorgstilbud for alle leger og medisinstudenter. http://legeforeningen.no/kollegastotte (29.11.2016)

2. Isaksson Rø K. Støttekollegaordningen for leger i Norge sett fra støttekollegenes side. En kvalitativ evaluering. Mastergrad. Oslo: Universitetet i Oslo, 2015.

3. Isaksson Rø K, Aasland O. Støttelegers syn på støttekollegaordningen. Tidsskr Nor Legeforen 2016; 136: 313-6

4. Isaksson Rø K, Veggeland F, Aasland OG. Peer counselling for doctors in Norway: A qualitative study of the relationship between support and surveillance. Soc Sci Med 2016; 162: 193-200. 